Insights offered into the role of a competitor orientation to sustain rural clusters.

Extends understanding of the value co-creation and sales performance relationship.

Highlights varying strategies across different product-markets served by firms.

Provides insights into firms' network relationships within and across clusters. 


\title{
Competitor orientation and value co-creation in sustaining rural New Zealand wine producers
}

\author{
James M. Crick, Dave Crick and Natalie Tebbett
}

\section{Address for Correspondence:}

Dave Crick, University of Ottawa, Telfer School of Management, Ontario K1N 6N5 Canada. Email: dcrick@uottawa.ca; Tel: +16135625800 Ext.4916

Biography: Dr. James M. Crick is a Lecturer in Marketing at the Business School, Loughborough University, UK. His current research interests involve work in Entrepreneurial Marketing and International Strategy; particularly work that addresses competitiveness.

Biography: Dr. Dave Crick is the Paul Desmarais Professor of International Entrepreneurship and Marketing in the Telfer School of Management at the University of Ottawa, Canada. His current research interests involve work at the Marketing/International Entrepreneurship interface and particularly work that addresses a more effective public/private sector interaction.

Biography: Dr. Natalie Tebbett is a Researcher in Geography, Department of Geography and Environment, Loughborough University, UK. Her current interests involve work at the intersection between geography and business.

\begin{abstract}
This study, underpinned by the Resource-Based View and its association with the Relational View, contributes to the existing cross-disciplinary literature involving economic geography, tourism and marketing by extending the current understanding of the relationship between firms' value cocreation activities and sales performance in the context of rural wine producing firms. Specifically, by investigating how a firm's competitor orientation (possessing and acting upon knowledge of competitors) affects the relationship between firms' capabilities to engage in value co-creation activities and sales performance. This investigation utilises a multi-level qualitative investigation within small-to-medium-sized, New Zealand wine producers engaging in various value co-creation activities (wine hospitality and tourism such as accommodation and restaurants through to wine sales, including at cellar doors). The methods employed involved 40 interviews across 20 businesses; observations of cellar door employees in all 20 firms; and collection of archival data. The findings reveal that by having a high degree of a competitor orientation, the enhanced value co-creation activities can help individual companies improve sales performance and support cluster sustainability, including via repeat tourism. However, results vary among competing businesses based on the product-markets served, where illustrations of potential tensions highlight the need for the management of complementary relationships, within and across clusters (the latter typically being to serve overseas markets). This study consequently offers new unique insights that explain strategies affecting not just an individual firm's performance, but also, the sustainability of other businesses.
\end{abstract}

Keywords: Co-creation; competitor orientation; rural clusters; performance. 


\title{
Competitor orientation and value co-creation in sustaining rural New Zealand wine producers
}

\begin{abstract}
This study, underpinned by the Resource-Based View and its association with the Relational View, contributes to the existing cross-disciplinary literature involving economic geography, tourism and marketing by extending the current understanding of the relationship between firms' value cocreation activities and sales performance in the context of rural wine producing firms. Specifically, by investigating how a firm's competitor orientation (possessing and acting upon knowledge of competitors) affects the relationship between firms' capabilities to engage in value co-creation activities and sales performance. This investigation utilises a multi-level qualitative investigation within small-to-medium-sized, New Zealand wine producers engaging in various value co-creation activities (wine hospitality and tourism such as accommodation and restaurants through to wine sales, including at cellar doors). The methods employed involved 40 interviews across 20 businesses; observations of cellar door employees in all 20 firms; and collection of archival data. The findings reveal that by having a high degree of a competitor orientation, the enhanced value co-creation activities can help individual companies improve sales performance and support cluster sustainability, including via repeat tourism. However, results vary among competing businesses based on the product-markets served, where illustrations of potential tensions highlight the need for the management of complementary relationships, within and across clusters (the latter typically being to serve overseas markets). This study consequently offers new unique insights that explain strategies affecting not just an individual firm's performance, but also, the sustainability of other businesses.
\end{abstract}

Keywords: Co-creation; competitor orientation; rural clusters; performance.

\section{Introduction}

The need to create value for customers in firms' performance-enhancing strategies is a fundamental consideration for owner-managers' business models across a variety of sectors (Osterwalder and Pigneur, 2010; Gassmann et al., 2014). Within the context of this current investigation that features wine producing firms based in rural clusters, research involving value-adding strategies has received a good deal of interest in cross-disciplinary studies, such as, economic geography, tourism and marketing (Mitchell and Hall, 2006; Randall and Mitchell, 2008; Charters et al., 2009; Felzensztein et al., 2014a; Baird et al., 2018; Crick, 2018). In fact, existing literature, not least related to agriculture and tourism, notes the importance of leveraging resources like via alliances and pivoting aspects of business models; such as, through diversification, to add value to customer groups as a performanceenhancing strategy (McNally, 2001; Alsos and Carter, 2006; Mitchell and Schreiber, 2006; Brandth and Haugen, 2011; Hansson et al., 2013). 
Specifically, the notion of 'value co-creation' activities (Alves et al., 2016; Chathoth et al., 2016; Tu et al., 2018) features in existing research; however, as Alves et al. (2016) point out, usage of the term and the contexts applied has varied. Bendapundi and Leone (2003) consider the notion of customer participation in production. Nevertheless, other studies suggest co-creation is a 'process' in adding value that is supported by relevant parties and often with end-users playing a central role (Jansen and Pieters, 2017). Indeed, Prahalad and Ramaswamy (2004) consider the joint creation of value allowing the customer to co-construct the service experience in their own context. Therefore, by way of clarifying the first core concept within this current study, value co-creation activities essentially involve owner-managers and their employees ${ }^{1}$ creating a positive experience by interacting with customers in order to improve respective firms' value provisions (Payne et al., 2008; Edvardsson et al., 2011; Tu et al., 2018).

Value co-creation is potentially important to sustain certain rural clusters, although the impact on individual firms varies as studies highlight that strategies vary across product-markets that are served (Dana and Winstone, 2008; Felzensztein et al., 2014b; 2018; Crick and Crick, 2015; Granata et al., 2018). For example, Crick and Crick (2015) highlight that certain wine producing firms target international markets with core wine sales and hence often sell via distributors rather than to endusers; in contrast, others rely on domestic wine sales and tourism, such as, sales to consumers at cellar doors. Consequently, in supporting both their own business and those in their regional cluster, particular owner-managers employ contrasting business models (Osterwalder and Pigneur, 2010; Gassmann et al., 2014) where knowledge of competitors' strategies is important to add value to customers. For example, earlier literature highlights the importance of wine tours and wine routes where there are knowledge spill-over effects and both traded and untraded dependencies among network partners (Mitchell and Hall, 2001; Bruwer, 2003; Crick and Crick, 2015; Crick, 2018).

\footnotetext{
${ }^{1}$ Hereafter termed 'employees' unless there is a need to distinguish between owner-managers and operational level staff members.
} 
Illustrations from earlier literature include knowledge resulting from informal wine tasting meetings in a cluster to maintain quality and establishing what rival wine producers offer, namely, varietals of wine in addition to on-site cafes, restaurants, etc. to enhance customers' experiences (Crick, 2018). Some dependencies are more tangible in comparison to others, where there are clearly shared benefits. Examples include between simply wine producers, growers, etc. in supply chains; additionally, the dependency of non-wine producing firms in a region like food and accommodation providers (Dana and Winstone, 2008). Certain dependencies are ongoing while others take place in response to events; in fact, a recent study by Cradock-Henry and Fountain (2019) considers building resilience among stakeholders in a region after a natural disaster.

Given the importance of the sustainability of particular clusters to various countries' economies (Felzensztein et al., 2014b; 2018; Geldes et al., 2015; Granata et al., 2018), it is not surprising that interest continues in the cross-disciplinary literature. In the specific case of this current study, the research boundary involves rural, small-to-medium sized wine producing firms in New Zealand. This is a research agenda that has witnessed a growing scholarly interest (see, for example, Hayward and Lewis, 2008; Overton and Heitger, 2008; Dawson et al., 2011; Howland, 2014; Perkins et al., 2015; Woodfield and Husted, 2017; Crick, 2018; Felzensztein et al., 2019). Earlier research has established the importance of collaboration activities among competing firms to support clusters. For example, instead of employees simply interacting with customers to create varying degrees of value, collaboration in addition to competition can also exist among rival firms to sustain clusters, like sharing equipment, engaging in educational events, joint promotions in both domestic and international markets, etc. (Dana and Winstone, 2008; Dana et al., 2013; Crick, 2018; Granata et al., 2018). Moreover, relationships can vary based on geographic and associated network proximities among firms in clusters (Geldes et al., 2015).

Such considerations lead to the second core concept in this current investigation that involves 'competitor orientation'; this arises when employees possess and act on knowledge of the activities, 
strengths, and weaknesses of their own respective firm's competitors (Narver and Slater, 1990). Earlier research has linked this to assisting firms' performance (Slater and Narver, 2000; Wang and Miao, 2015). Nevertheless, performance as the third core concept in this current study has been measured in various ways in the cross-disciplinary literature ranging from objective terms like sales through to subjective criteria like owner-managers' objectives (Armstrong and Collopy, 1996; Verbeke et al., 2008; Le Roy and Sanou, 2014; Katsikeas et al., 2016). Sales performance appears consistent with many earlier studies and so features in this investigation. Linking the three core concepts mentioned so far, the extent to which firms in rural clusters engage in competitor-oriented activities to co-create value in order to enhance performance or even simply sustain their own respective business and the cluster as a whole, remains under-researched. Consequently, this study's research objective is to investigate how a firm's competitor orientation affects the relationship between value co-creation activities and sales performance in a rural context.

In contributing to knowledge, from a Resource-Based View (RBV) perspective, existing literature has established that companies can utilise their own resources and capabilities to enhance performance (Barney, 1991; 2014) and not least via engaging in value-adding activities (Li and Petrick, 2008; Madhavaram and Hunt, 2008). Furthermore, studies suggest that if under-resourced firms build quality relationships with their competitors consistent with the associated Relational View (Dyer and Singh 1998; Dyer et al, 2018), they can access more complementary resources and capabilities to enhance performance compared to operating on an individualistic basis (Combs and Ketchen Jnr, 1999; Ritala, 2012). This resource-enhancing approach makes the RBV together with the associated Relational View appropriate lenses to underpin the current investigation in order to offer unique insights into firms' practices within rural clusters. This current study is important, since it follows that a competitor orientation can add to a firm's value-adding capabilities to enhance its own and rival businesses' performance. This cross-disciplinary study extends the ongoing development of economic geography, tourism and marketing research (see Overton and Murray, 
2011; Rainer, 2016; Crick, 2018; Dias et al., 2019). Moreover, this investigation is timely and addresses a recent call by Bonn et al. (2018), after their review of wine studies in cross-disciplinary research domains, for a continued refinement of knowledge to add to the understanding of firms' practices. Furthermore, it addresses the calls by Crick (2018) and Granata et al. (2018) for research that offers further insights into collaborative activities to support the sustainability of clusters in addition to individual firms.

Consequently, this current study's first contribution is to provide unique insights concerning the benefits for firms of possessing market intelligence pertaining to competitors' activities, and inputting this knowledge (as a capability) into value co-creation activities to enhance sales performance. In doing so, this investigation therefore builds on the Relational View's association with the RBV accounting for trust and the quality of complementary network relationships (Dyer and Singh, 1998; Dyer et al., 2018) to minimise potential tensions within the competitive business environment (Priem and Butler, 2001). Specifically, by linking value co-creation activities with firms' competitor orientation, connection takes place of the domains of business-to-business and business-to-consumer strategies in rural contexts to extend the current cross-disciplinary body of knowledge.

This study's second contribution is to provide unique insights into the varying strategies among firms that highlight the importance for accounting for product-markets served (Felzensztein et al., 2014b; 2018; Crick and Crick, 2015; Granata et al., 2018). A competitor orientation manifests differently based on whether owner-managers' respective strategic focus involves wine sales and tourism in their domestic market as opposed to overseas sales of wine. By acting on competitor intelligence to create value and a positive customer experience, this enhances benefits for firms in a cluster (such as via repeat tourism and sales) for those with a domestic market focus in their business model. This is in contrast to those firms that focus on overseas sales via distributors that have less motivation to bring repeat tourism to clusters. The third contribution features potential negative activities resulting from a competitor orientation as opposed to benefits that feature in much of the existing literature. The 
study therefore provides insights into a rationale for cross-cluster relationships as opposed to simply within-cluster relationships, the latter featuring in much of the existing literature. In addition to the theoretical contribution, this current study has implications for practitioners; that is, recommendations in respect of how employees can add value to the customer service experience compared to if they did not possess and act on competitive intelligence. The research question follows:

RQ: How does a firm's competitor orientation affect the relationship between value co-creation activities and sales performance?

In the remainder of the paper, first, the researchers outline the conceptual and theoretical underpinnings that inform this current investigation, showing how networking and knowledge exchange activities are important to under-resourced firms in rural clusters. Moreover, contextualisation takes place in that section regarding the notion of 'clusters' together with the formulation of research propositions. Second, there is a discussion about the research methods undertaken, including contextual factors, data collection, and analysis. Taking the example of New Zealand, the investigation then proceeds with a presentation of the empirical findings that align to the study's two-fold research propositions. The paper ends by outlining contributions to knowledge, together with associated conclusions, implications and areas for future research.

\section{Literature Review}

\subsection{Theoretical Lenses - RBV and the Associated Relational View}

The theoretical lenses underpinning this investigation are the RBV and the associated Relational View. The RBV is utilised in earlier research to understand how companies' resources and capabilities drive organisational performance (Barney, 1991; 2014). Resources are tangible assets, like cash and equipment, whereas capabilities are intangible assets, such as, knowledge and experience (Barney, 2001; Priem and Butler, 2001). Turning to the performance-enhancing nature of resources/capabilities, existing research features considerations in respect of the value, rarity, 
imitability, and non-substitutability of these organisational assets (Barney, 1991). An assumption within the RBV in the context of this current study, namely, involving under-resourced small-tomedium sized wine producers, is that smaller-sized firms are typically constrained due to the likelihood of possessing limited resources/capabilities (Barney, 2001). Nevertheless, Barney (2018) more recently notes the potential role of stakeholders; that is, providing a prima facie rationale to engage in competitor-oriented behaviour in order to know what rivals are doing and leverage associated resources/capabilities. For example, as mentioned earlier, in the context of the wine sector this may involve information sharing, wine tours, joint promotions, etc. (Bruwer, 2003; Crick, 2018; Granata et al., 2018). Such considerations subsequently lead to the RBV's association with the Relational View (Dyer and Singh, 1998; Dyer et al., 2018), whereby the quality of network relationships can enhance the performance consequences of strategies. It follows that the RBV together with the Relational View are appropriate lenses to underpin this investigation.

Existing studies involving value co-creation have largely recognised the potential, positive link with firms' performance. For example, by interacting with customers, employees build capabilities as they gain experience in respect of what factors are required to deliver value to their targeted customer segments, and thus, can adapt their strategies towards the issues that customers require (Payne et al., 2008; O'Cass and Ngo, 2011). Consistent with the RBV and associated Relational View, potential reasons that value co-creation activities allow companies to enhance their sales performance are often underpinned by the resources and/or capabilities that organisations can utilise when interacting with customers (Edvardsson et al., 2011; Cabiddu et al., 2013; Prebensen et al., 2013). Moreover, collaboration with competitors to enhance respective firms' resources bases (Combs and Ketchen Jr., 1999; Granata et al., 2018), or at least acting on knowledge to overcome limited resources and capabilities, can assist firms' performance via a competitor orientation (Slater and Narver, 2000; Seilov, 2015; Wang and Miao, 2015). It is nonetheless important that management of expectations 
occur between network partners to reduce potential tensions (Raza-Ullah et al., 2014; Tidström, 2014).

\subsection{Clusters and Context}

Porter (2000, p.16) views clusters as "geographic concentrations of interconnected companies, specialized suppliers, service providers, firms in related industries, and associated institutions (e.g., universities, standards agencies, trade associations) in a particular field that compete but also cooperate". Nevertheless, Porter (2000) suggests that the appropriate definition of a cluster can vary across locations, depending on the segments in which the member companies compete and the strategies employed. Consequently, the notion of 'clusters' is important to clarify within a respective study given that earlier research features various business contexts; that is, with their own institutional conditions and respective weak and strong ties among network partners. Examples include: creative clusters in non-metropolitan areas (Escalona-Orcao et al., 2016), creative food clusters (Lee et al., 2015) and farmers' markets (Onederra-Aramendi et al., 2018) in rural areas, clusters of restaurants in urban areas typified by ethnic enclaves (Crick et al., 2016), through to this current study featuring wine producing firms in rural clusters (Dana and Winstone, 2008). It follows that context is therefore important within research investigations (Jones and Rowley, 2011). In the context of this current New Zealand based study, typically, smaller-sized wine producers are located within clusters, meaning wine growing regions (Dana and Winstone, 2008; Dana et al., 2013; Crick, 2018), as shown in Appendix 1. Earlier research in the wine industry context highlights the potential synergistic relationships that can result from networks within particular clusters leading to economic development; not least, via firms' network ties that extend to sharing of resources and capabilities (Felzensztein and Deans, 2013; Crick and Crick, 2015; Granata et al., 2018).

Nevertheless, in terms of wine producers' product-market strategies, it is widely recognised that some businesses focus on wine sales domestically and abroad as opposed to others that offer a diversified 
portfolio aimed at domestic hospitality and tourism (Dana and Winstone, 2008; Dana et al., 2013; Charters and Michaux, 2014; Crick and Crick, 2015; Granata et al., 2018). For example, in pursuing opportunities, some wine producers are motivated to operate an export-oriented business model for reasons such as growth and the benefit from excise tax advantages (Crick and Crick, 2015) similar to examples in other sector contexts like Australian craft beer (Argent, 2018). In contrast, various factors encourage wine tourists to visit a particular region in a country providing opportunities for firms pursuing a domestic market focus, such as the image, landscape, the site of production; also, seasonality can affect the timing of visits (Hall and Mitchell, 2000; Mitchell and Hall, 2003; Mitchell et al., 2012; Bruwer et al., 2018). Moreover, various interactions take place at cellar door tasting rooms to facilitate a service encounter and encourage brand loyalty and post visit purchases (Fountain et al., 2008; Hollebeek and Brodie, 2009; Charters et al., 2009; Fountain, 2018). While service encounters are important (O’Neill et al., 2002), wine tourists are not a standardised group to whom the service is offered (Charters and Ali-Knight, 2002). Expectations and engagement may vary, such as, across novice and experienced wine consumers, different nationalities and age groups. For example, recently, Fountain (2018) found that Chinese visitors were interested in learning about wine and wine making, engaging in tasting; also, hearing stories about wine. It follows that understanding differences across consumer groups and learning from competitors how to co-create a positive experience, can enhance wine producers' performance.

The contextual issue of 'place' is important. For example, some clusters are more geographically dense with firms having various proximity and network ties in particular countries (Dana and Winstone, 2008; Dana et al., 2013; Felzensztein and Deans, 2013; Geldes et al., 2015; Granata et al., 2018). In respect of this current investigation, the findings from these earlier studies suggest that despite the competitive intensity within clusters (consistent with Priem and Butler, 2001), from a geographic perspective, the notion of 'proximity' potentially affects employees' knowledge of, and relationships with, competing businesses as stakeholders consistent with the Relational View and the 
RBV (Dyer and Singh, 1998; Barney, 2018). This is important since certain firms in rural clusters, typified by having limited resources, need to develop a positive customer experience to facilitate hospitality and tourism activities in additional to core wine sales and assist their (and the cluster's) enduring entrepreneurial activities. This includes developing firms' positive brand images and tourism reputation within clusters, not least to motivate the purchase of the wine and return tourism (Mitchell and Hall, 2001; Telfer, 2001; Beverland, 2005; Brown and Getz, 2005; Hollebeek and Brodie, 2009; Voronov et al., 2013; Afonso et al., 2018). For example, Bruwer (2003) discusses the nature of wine routes. These vary in nature, but often allow customers to co-create a wine hospitality and tourism 'experience' across geographic regions by visiting a number of cellar doors on a wine route and potentially other facilities like restaurants in a respective cluster.

The New Zealand wine industry featuring in this current study is part of what is termed the 'New World', alongside countries, such as, Australia, South Africa, the United States, and Chile (Aylward, 2003). Such 'New World' wine producing countries contrast with 'Old World' wine producing countries like France and Italy, since the latter have a far longer heritage of wine production. While New Zealand accounts for less than $2 \%$ of worldwide wine production, the country produces a range of varietals, such as Sauvignon Blanc, Pinot Noir, Chardonnay, and Pinot Gris (New Zealand Winegrowers, 2018). As previously alluded to and illustrated in Appendix 1, New Zealand hosts various wine-producing regions, with the main one being Marlborough, but others include Central Otago, Auckland, Hawkes Bay, and Waipara (Murray and Overton, 2011). Appendix 1 provides a map of the New Zealand wine industry. The sector comprises of firms with varying relationships like growers, producers, those that undertake bottling etc., namely, that affect network ties in clusters (Dana and Winstone, 2008).

Certain institutional factors are worthy of consideration and in particular the role of New Zealand Winegrowers (New Zealand Winegrowers, 2018). According to the industry body's website, advantages to support members include: advocacy at regional, national and international levels; a 
global platform for New Zealand wine; facilitating research on industry practices; providing members with information; leading development on sustainable production practices; and, organising sectorwide events. The website also indicates that: "New Zealand Winegrowers' Sustainability Policy requires all wine to be made from $100 \%$ certified grapes in fully certified winemaking facilities" (New Zealand Winegrowers, 2018). In fact, to gain export assistance, producers need to be part of the Sustainable Winegrowing scheme.

\subsection{Development of the Research Propositions}

In this current study, value co-creation activities are considered in respect of the ways in which companies (or more specifically, employees) cooperate with their customers to improve their service delivery and maximize their value provision (Vargo and Lusch, 2008; Grönroos and Voima, 2013). Various conceptualisations exist for value co-creation activities, with a focus being on interaction, such as, the sharing of knowledge between organisations and customers, pertaining to how value can be improved (Ramirez; 1999; Ballantyne and Varey, 2008; Edvardsson et al., 2011; Ranjan and Read, 2016; Prebensen and Xie, 2017). Value co-creation activities underpin service-dominant logic, a service-driven strategy used to understand how to deliver value to customers (Day et al., 2004; Vargo and Lusch, 2004; Prebensen et al., 2013). Service-dominant logic is a managerial mind-set pertaining to service being an integral driver of performance (Vargo and Lusch, 2008). Nevertheless, conceptualisation of organisational performance has varied in earlier studies using objective and subjective measures; for example, sales performance, competitive advantages, and market-level survival (see Gray et al., 2000; Verbeke et al., 2008; Le Roy and Sanou, 2014; Katsikeas et al., 2016). Sales performance is a common measure and hence used in this current investigation.

It follows that value co-creation exists where buyers and sellers cooperate to create a positive experience for customers, and not least, companies can tailor their products and services towards the wants/needs of their customers (Payne et al., 2008; Ranjan and Read, 2016). Moreover, customers benefit from co-creation strategies, as they are likely to be provided with value, compared to dealing 
with organisations that are less engaging (Grönroos and Voima, 2013; Prebensen and Xie, 2017). As such, by co-creating value with customers, employees are more likely to receive knowledge about better methods to provide value (Madhavaram and Hunt, 2008; Sørensen and Jensen, 2015). In other words, if employees can be responsive to the knowledge/experience that they receive from customer interactions, they should be able to deliver value and develop a stronger value provision, ultimately enhancing sales performance. It follows that:

\section{P1. Value co-creation activities have a positive relationship with sales performance.}

Although the relationship in P1 is largely established, particular 'how and why' issues of a qualitative nature are relatively under-researched, and hence the core contribution of this study arises from proposition $2(\mathrm{P} 2)$. Specifically, the relationship with a competitor orientation requires further investigation; that is, aligned to the broader notion of market orientation. Market orientation concerns the organisation-wide creation of customer value, in which companies strive to develop a customer value provision that out-performs their rivals (Slater, 1997; Wu, 2004). Moreover, Narver and Slater (1990, p.21) defined competitor orientation involving when "a seller understands the short-term strengths, weaknesses, long-term capabilities, and strategies of both the key current and the key potential competitors".

Knowledge of competitors' activities may be an influential driver in improving the quality of businesses' value co-creation strategies, and thus, may be a factor that increases the chances of firms being able to drive their individual sales and those within particular network relationships. If employees have access to intelligence about the activities of their competitors (and their competitive strategies), they could be able to develop counter-strategies (Cadogan and Diamantopoulos, 1995; Armstrong and Collopy, 1996), or collaborative activities that are often important in clusters (Dana et al., 2013; Geldes et al., 2015; Granata et al., 2018). Hence, if organisations acquire and act on market intelligence pertaining to their competitors' activities, it follows that they can develop value co-creation activities to aid competitiveness. Therefore, it is expected that: 
P2. A firm's competitor orientation influences the relationship between value co-creation activities and sales performance.

\section{Methods}

\subsection{Empirical Context}

This study primarily involved forty interviews across 20 wine producing firms, but data collection also utilised various sources to gain a relatively in-depth understanding of the empirical context. Although this current study features wine producers, several also grew grapes for other firms, but none pressed or bottled wine for other producers. In avoiding large-scale producers due to their greater resource base, it was important to capture small-to-medium sized wine producers with particular product-market strategies in this current investigation to gain unique insights into particular firms' practices. In the first instance, use was made of the New Zealand Winegrowers' database. Subsequently, via varying supporting contact details from that database with additional information (like websites), identification was made of 726 potential firms.

From this population list, the researchers further studied secondary data including the extant literature and websites of all the companies. This led to a refined judgement-based sample following practitioners' recommendations (see the later details on pre-testing) of 100 businesses that were diverse in terms of their wine varietals and tourism services, firm size, and firm age. In respect of geographic location, they were located across several wine regions over the north and south islands. Nevertheless, omission took place of company names and demographic characteristics associated with firms across regions to avoid identification of individual wine producers. There is no single agreed definition of firm size (Granata et al., 2018) that can include criteria involving, for example, annual production, turnover, employees, etc.; however, the current study focused on small-to-medium sized enterprises, namely up to 99 employees, that appears consistent with avoiding criteria for largersized firms. When contacting these organisations, the researchers stressed to the owner-managers that 
if they agreed to participate in this study, multiple sources of empirical and archival data would be required (as per Riley and Love, 2000).

One key aspect of the data collection involved interviewees being asked about key relationships as that was not apparent from the secondary data available; this facilitated invitations with further interviewees within and across the wine clusters selected. A decision took place not to focus on a single wine producing area to establish local relationships in-depth (as per studies like Dana and Winstone, 2008). Rather, the preliminary interviews with practitioners established the need to consider relationships within and across regions to account for domestic and internationally oriented business models whereby the nature of relationships might vary. Data collection took place at the wine producers' respective firms and involved the same member of the research team of three. This ended with 20 businesses as a point of theoretical saturation was reached (the analysis section provides more details). There was no pre-set attempt to collect data from a specific number of wine producers in each region and rather the idea was to wait until diseconomies in collecting new/different themes occurred. Furthermore, the interviews with owners and Cellar Door Managers in each of the 20 firms (40 interviews in total) took place on the same day when possible (with a couple of exceptions due to availability), but at different times; also, observations took place on the same day lasting about 3 hours. The timescale was within a period of approximately two months in 2017. Cellar door members of staff were observed (during quiet and busy times) regarding the ways in which they engaged in value co-creation activities. However, observation was not the substantive aspect of data collection (more for triangulation), but rather the interviews, as this was not an ethnographic investigation. Recording of interviews lasting approximately 60-90 minutes took place, but subsequent observation involved field notes. Initial planning of the timescale for data collection was to minimise perceptions based on changes in economic circumstances that may occur over longer periods. However, some interviews with owner-managers were difficult to arrange, as they were busy at events such as promotions or setting up distribution agreements. 


\subsection{Data Collection Techniques}

Initially, exploratory research took place involving semi-structured interviews with a combination of 10 academics and practitioners (including a senior member of New Zealand Winegrowers) to develop suitable interview questions for the subsequent core study, as well as to formulate concepts and an effective sampling strategy. These academics and practitioners were knowledgeable about the focus of the study, and helped the research team convert the interview questions sourced from the extant literature (see, for example, Beverland, 2005; Voronov et al., 2013; Jaskiewicz et al., 2015) into ones that would more accurately evaluate the research propositions. Data collection followed in the manner described in the previous section.

These interviews were divided into two sections, beginning with some background demographic questions about their organisations (like firm size, firm age, and export ratios), before asking questions pertaining to the research question. The purpose of these interviews was to investigate the ways in which the sampled organisations engaged in value co-creation activities as well as possessing and acting on knowledge about their competitors (a competitor orientation) and performance implications. The semi-structured interviews were effective in understanding in-depth information pertaining to the issues under investigation. However, by observing those working at the functionallevels of all 20 firms the researchers could record via field notes how the employment of value cocreation activities occurred in practice. Collection of archival data took place in respect of each organisation, such as websites, company reports, industry statistics, and other media releases. Triangulation of the data (Winchester and Rofe, 2010) enabled the researchers to look for similarities and differences ${ }^{2}$. The selected data analysis techniques follow in the next section.

\footnotetext{
2 The volume of archival data varied by company and typically more was available from the longer established firms. Omission of demographic characteristics is to maintain confidentiality.
} 


\subsection{Data Analysis}

Rigour as well as relevance in research is important, although analysis approaches vary and earlier studies have questioned terminology like 'reliability' and 'validity' in relation to qualitative as opposed to quantitative data. For that reason, this investigation followed the guidelines of Morrow (2005) relating to the 'trustworthiness' of the data. Manual coding allowed the researchers to get closer to the data that included practitioner discourse related to research 'issues' under investigation (the term 'issues' is consistent with Stake, 1995). Progressive focussing involved the researchers sifting through the data for themes developed from the first part of the data analysis stage (based on the underpinning literature), and screening-out all other themes (Sinkovics and Alfoldi, 2012). The researchers used the constant comparison technique; that is, comparison of the data from the first sampled company took place with the equivalent data from the second sampled company and repeated, namely, until data from all 20 firms was utilised. This approach allowed the research team to acknowledge when a point of theoretical saturation had occurred, to end the data collection stage, but still maintain 'trustworthiness' in the data collection (Morrow, 2005).

'Bracketing' was employed, namely a technique that involves presenting qualitative data in the words of interviewees, rather than the words of researchers so that such data is not accidentally misconstrued (Tosey et al., 2014). This means that some quotes in the subsequent section are not grammatically correct. The study employed an "adapted" version of the "Gioia methodology" (Gioia et al., 2013), in which the data indicated how the themes connected to one another. For clarity, particular studies present data associated with the Gioia methodology differently (for example, Jaskiewicz et al., 2015). Specifically, certain studies are more inductive in nature. The adapted Gioia methodology summarised in Figure 1 involved evaluating how a series of illustrative quotes (primary codes) related to the key themes associated with the findings (secondary codes), and in turn, how such themes were associated with the aggregate dimension (research question). As such, certain prescribed themes were 
utilised and the adapted Gioia methodology outlines the process for the purposes of robustness in this study's research design.

\section{Findings}

\subsection{Sample Characteristics and Perceptions of Performance}

Table 1 provides an overview of the 20 sampled firms' selected characteristics, with some targeting predominately core wine sales, whereas others offered a wider array of wine hospitality and tourism services (weddings, accommodation, and restaurants). There was a mixture of firm ages, with a mean $=26.15$ years. This information allowed the investigation of the background among organisations, and their heritage. Furthermore, some wine producers were highly internationalised, whereas, others were minimally involved in overseas markets $($ mean $=40.30 \%)$.

These background characteristics help explain all owner-managers' perceptions related to performance and not least due to differences among product-markets served. However, it is emphasised that each owner-manager's discourse varied in terms of performance measurement, but all perceived their respective firms were successful against objectives set. For example, consistent with the RBV, small, boutique wine producers could not compete in the same way as those with more resources that could operate a diversified portfolio, such as a restaurant in addition to core wine sales. In fact, all owner-managers stated that sales performance against objectives need to be measured with a time horizon in mind, since certain strategies like entering an overseas market can often take time and resources. Development of such considerations takes place in further detail related to the research propositions in subsequent sections of this investigation.

\subsection{Wine Products and Services}

In terms of the degree of wine hospitality and tourism in addition to core wine sales, the 20 sampled businesses offered at least some augmented services. In fact, by design, all 20 companies had a cellar 
door. The types of wine services offered depended on the firms' size, whereby, those with more employees typically offered a higher degree of options; however, all were small-to-medium sized. Owner-managers employed their own forms of wine hospitality and tourism as part of their respective firms' business models (cellar doors, restaurants, etc.), but some also had partnerships with local nonwine sector firms. For instance, Firm 18 focused on the domestic market offering a variety of winerelated services; it also had connections with companies engaged in adrenaline sports. This collaboration involved tour operators stopping at the wine producer to give post-adrenaline infused tourists (and other consumers such as friends) an opportunity to buy wine at the cellar door, make a reservation at the restaurant, and partake in other forms of wine hospitality and tourism. It is now useful to look at data addressing the research propositions in more detail.

\subsection{Value Co-creation Activities and Sales Performance}

Not surprisingly, in support of the first proposition that has already been widely addressed in earlier literature, all interviewees provided evidence of engaging in co-creation activities, in which the employees were active in working with customers for a mutually beneficial sales performance outcome within their cluster. Specifically, their respective geographic region shown in Appendix 1, where network relationships existed among firms (as per Porter, 2000). Importantly, business models were more focused towards serving overseas markets within two specific firms (these other wine producers are considered in their own right later), and so behaviour was different to the majority with a domestic focus, such as interactions at the cellar door. For example, in terms of the companies that had a motive to support tourism in their cluster, the owner-manager in Firm 4 stated that "our customers tell us all sorts of things; they give us advice whenever we ask for their help, and we try our best to improve our service, depending on what they say”. Moreover, the Cellar Door Manager in Firm 13 noted, “as part of my job, service is my number-one priority. If I can't provide a good service to customers, then I'm not doing my job properly. As I know most of my customers quite well, 
since they're regulars, I'm always asking for tips on how I can do better, and they're often prepared to tell me”.

In terms of proposition 1, in all 20 firms, the owner-managers indicated that there is a positive relationship between value co-creation activities and sales performance, although the way this manifested itself across product-markets varied. Specifically, they highlighted that by cooperating with customers and obtaining knowledge about how to improve their service delivery, their sales across a range of wine products and related services (cellar doors, accommodation, and restaurants) had grown. An example follows from the owner-manager of Firm 6, namely, "it's a competitive market out there. So, we as a business, need to do everything within our power to make sure customers are pleased with their experience here. The main way we make sure this happens is through our ability to tell an interesting story, as we offer a range of things [wine-related services] that appeal to most people [customers]”. By offering a selection of augmented services (value co-creation opportunities), interviewees in 18 out of the 20 companies stated that they could create a positive experience for customers, and in turn, improve their sales performance.

Ownership of the other two organisations was respectively via individuals with objectives focused on export markets rather than domestic-oriented value co-creation activities (namely, Firms 1 and 20). Apart from visitors such as potential distributors, interviewees in both firms perceived they had little need to actively co-create an experience with customers at the cellar door as they accounted for such a small part of their sales and often turned up to sample free wine with no intention of buying so could be a potential hindrance. However, both did acknowledge the need to build positive, value-adding relationships with distributors that would sell their wine overseas; these were in effect their customers in a business-to-business rather than business-to-consumer sense, namely, not the final consumers of the wine. 
Figure 1: Data structure

Illustrative quotes
Key themes

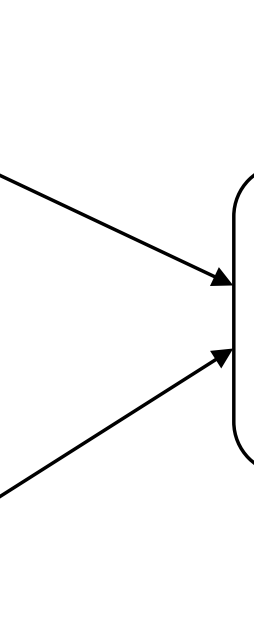

creation activities

and sales

performance

"Customers sometimes like to have dinner, have a tour around the vineyard, and perhaps buy

something [wine] at the cellar door. I make sure they get everything they want so they come back or at least buy more wine" (Firm 17).

"If we don't offer something ourselves, we will always recommend someone close by

[competitor]. As we know what each other [competitors] are doing, it's easy to point customers in the right direction" (Firm 6).

"Some customers came into the cellar door... about to get married. They knew we don't offer a wedding service, but weren't sure who in [region withheld] does... I pointed them in the direction of [firm withheld - a competitor]" (Firm 11). 
Table 1: Selected characteristics of the sampled companies

\begin{tabular}{|c|c|c|c|c|c|c|}
\hline Firm & Functional title of the interviewees & $\begin{array}{l}\text { Average } \\
\text { price }^{1}\end{array}$ & \begin{tabular}{|l|} 
Year \\
founded
\end{tabular} & $\begin{array}{l}\text { Full-time } \\
\text { employees }\end{array}$ & $\begin{array}{l}\text { Export } \\
\text { ratio }(\%)^{1}\end{array}$ & $\begin{array}{l}\text { Key export market(s) } \\
\text { (countries) })^{1}\end{array}$ \\
\hline 1 & Chief Wine-Maker and Cellar Door Manager & 16.99 & 1990 & 25 & $95 \%$ & United Kingdom \\
\hline 2 & Chief Executive Officer and Cellar Door Manager & 18.32 & 1989 & 60 & $40 \%$ & China, Japan \\
\hline 3 & Head Wine-Maker and Cellar Door Manager & 25.73 & 2003 & 29 & $0.5 \%$ & Not applicable \\
\hline 4 & Managing Director and Cellar Door Manager & 11.59 & 1992 & 10 & $5 \%$ & Not applicable \\
\hline 5 & Chief Operating Officer and Cellar Door Manager & 21.84 & 2002 & 50 & $80 \%$ & United Kingdom \\
\hline 6 & Head Wine-Maker and Cellar Door Manager & 37.82 & 1988 & 10 & $0.5 \%$ & Not applicable \\
\hline 7 & Director of Marketing and Cellar Door Manager & 18.94 & 1980 & 12 & $50 \%$ & China, Australia \\
\hline 8 & Managing Director and Cellar Door Manager & 16.99 & 1932 & 35 & $30 \%$ & Japan, United States \\
\hline 9 & Managing Director and Cellar Door Manager & 28.11 & 1999 & 18 & $50 \%$ & Canada, United States \\
\hline 10 & Managing Director and Cellar Door Manager & 17.88 & 1990 & 30 & $40 \%$ & United States, China \\
\hline 11 & Head Wine-Maker and Cellar Door Manager & 22.34 & 1988 & 12 & $10 \%$ & Australia \\
\hline 12 & Head Wine-Maker and Cellar Door Manager & 24.26 & 1989 & 24 & $65 \%$ & United Kingdom \\
\hline 13 & Marketing \& Sales Director and Cellar Door Manager & 28.56 & 1986 & 12 & $30 \%$ & China, Japan \\
\hline 14 & Director and Cellar Door Manager & 26.65 & 1986 & 17 & $80 \%$ & Kingdom, Canada \\
\hline 15 & Director of Sales and Cellar Door Manager & 34.55 & 2001 & 10 & $20 \%$ & United States, Australia \\
\hline 16 & Managing Director and Cellar Door Manager & 31.76 & 2000 & 15 & $30 \%$ & China, Hong Kong \\
\hline 17 & Marketing Director and Cellar Door Manager & 21.73 & 1998 & 15 & $50 \%$ & Germany \\
\hline 18 & Chief Executive Officer and Cellar Door Manager & 14.72 & 1987 & 60 & $5 \%$ & Not applicable \\
\hline 19 & Managing Director and Cellar Door Manager & 16.32 & 1999 & 60 & $30 \%$ & Australia, United States \\
\hline 20 & Managing Director and Cellar Door Manager & 17.30 & 1998 & 30 & $95 \%$ & Japan, Germany \\
\hline
\end{tabular}


As the owner-manager of Firm 1 pointed out: "we collaborate with local firms (competitors) like at regional wine tastings so the reputation of the quality of wine produced in (name of region withheld) does not suffer. You know, I mean if one firm lets the others down by producing something of poor quality where we all (rival producers in a cluster) suffer. However, on a day-to-day basis, cellar door sales are such a small part of the business that some of the things you are asking about (co-creation and competitor orientation) are not a big deal. My concern is that a distributor will be selective and so it is important to build trust with firms (competitors) elsewhere, so more of us get a chance (distributor arrangements for brands across different regions). Then there is something in it for us all (complementary performance-enhancing relationship)."

In short, all interviewees recognised the need to add value in particular ways to customers; that is, supporting proposition 1, already widely acknowledged in earlier studies. However, the contribution arising from the interviews regarding this proposition focused on the role of the respective business models including product-market(s) served by the wine producers, as this influenced responses across the 20 firms; namely, an issue that provided variance across interviewees. Specifically, the variance involved differences among firms in co-creation activities taking place with first, those whose business models focused on consumers in the domestic market (like at cellar doors) that affected the need to facilitate cluster-based relationships, namely, within their geographic regions. Second, among competing firms whose business models involved serving distributors in overseas markets; this influenced the need for rivals to facilitate network relationships across New Zealand's regional clusters.

\subsection{Role of a Firm's Competitor Orientation}

Given that a good deal of literature exists to support the first proposition, the core contribution of this study arises from proposition 2 and not least the variance among interviewees. Interviewees in all 20 
firms indicated the importance of possessing and acting upon knowledge about their competitors' activities to support their own firm's sales performance and in certain respects those of others within and outside of the respective cluster. However, within 16 firms in particular (differences between these 16 businesses and the other 4 are considered in their own right later), interviewees provided illustrations involving specific knowledge of strengths and weaknesses to help achieve a competitive advantage. Nevertheless, an underlying need existed for employees in all 20 firms to understand aspects of competitors' activities. This manifested in knowledge transfer among competitors in a region and across regions depending on the respective business model employed. For example, at the regional level, the issue alluded to in the last section involving wine tasting, so a firm did not provide poor quality wine to influence the reputation of the cluster in an adverse manner (and hence sales performance); namely, an informal policing of quality. In contrast, for those two firms with internationalised business models, the need existed for knowledge of complementary rivals outside of their cluster with whom to collaborate in the event an overseas distributor would only take one brand of a varietal from a region.

The owner-manager of Firm 18 explained in practitioner discourse the importance of possessing and acting upon knowledge of competitors to enhance performance. "(Cluster name withheld) is small and we all (competitors) share information to gain benefits. Some of us (wine producers) concentrate on international markets, but others like ourselves rely on selling to restaurants, hotels and so on. Of course, many of us rely on visitors in some way and I don't mean just at the cellar door or restaurant. We need to create a good experience and service is important so they continue to buy our wine when they go home. That's why it's good we know what others (competitors) offer so we can refer visitors if we don't offer a varietal and they can do the same for us. There is a good deal of trust locally because we all benefit, but I suppose if we found out that they (competitors) were not referring us the trust would disappear. However, we also collaborate with other local firms like (name of firm providing simply accommodation withheld), so they send visitors to us and we can do the same". 
This quote demonstrates information sharing for cross-referral purposes among particular rival firms based on complementary relationships. Specifically, those with a domestic-oriented business model who needed to facilitate repeat tourism and sales. Moreover, the quote highlights the need to collaborate with wider stakeholders, such as, those in the broad tourism sector to enhance customers' experiences in addition to enhancing sales performance from visits. The quote highlights the issue of trust and the need to manage potential tensions, for example, if rivals stopped referrals. A limited relationship existed among those with varying business models; that is, there was less need for a wine producer focussing on the domestic market to collaborate extensively with those focusing on international markets. As the owner-manager of Firm 18 proceeded to mention, "if someone (rival wine producer) is not interested in the local market (internationally-oriented business model) we have less to do with them because they simply don't have the same motivation to bring visitors to (region name withheld)". As such, there was a need to co-create a positive experience for customers visiting the region to benefit wine producers with a domestic tourism oriented business model.

A firm's competitor orientation resulted through various employees' network relationships with their competitors to varying degrees across all 20 wine producers. For example, the owner-manager in Firm 10 stated, "I'm good mates with pretty much everyone in [region withheld-competitors] and we see each other all the time in the streets and shops". The quote demonstrated an underlying degree of goodwill within the sector that appeared representative of interviewees' perceptions. However, considerations towards the density of clusters arose, since interview data indicated employees in smaller regions were far more knowledgeable about competitors than in larger geographically dispersed clusters. For example, an owner-manager located in Marlborough (firm number withheld for anonymity) noted "I know what the local vineyards [competitors] are doing, but am less sure what [named firm withheld] and others are doing as I have less to do with them. Some are part of different wine tours." This quote highlighted a variety of geographic and social ties (including quality of network relationships) among wine producers. The owner-manager of Firm 6 went further and 
pointed out one explanation, "in a region like ours, visitors hire bikes and call in to taste wine along their route. It makes sense to be able to know what others (competitors) offer so we can all recommend where customers should visit for say pinot noir, which we don't produce, or sav which as you know, we do sell, where to eat and so on. That's not the same in other regions where customers need to drive or be part of a tour to get around."

There was a clear link to sales performance in those same 16 out of the 20 firms when interviews took place with Cellar Door Managers to supplement the prior comments from owner-managers. Commencing with positive considerations, as previously mentioned, by knowing about competitors' strengths and weaknesses, employees (particularly, those working at the cellar door-level) could recommend rival organisations and their wine-related service activities in a cluster. For instance, the Cellar Door Manager in Firm 7 stated, "I'm always talking to folks at other vineyards [competitors], sharing ideas, and tricks of the trade. We like each other to do well”. This interviewee, like others discussed the importance of knowledge about competitors leading to an enhanced offering to customers that positively affected sales performance for those in the cluster where tourism was important. Specifically, a common example involved cross-referrals (similar to those mentioned by owner-managers) acting on competitor knowledge to enhance a customer's experience in a wine cluster. As the Cellar Door Manager of Firm 13 pointed out, "a customer may be staying (in the region) for a few nights and may not want to eat in the same place each night. It therefore makes sense to be able to recommend another restaurant (not always located at another wine producer) and so the customer gets a great experience and wants to return. Relationships like this are common as we have built trust with some of our neighbours (the term 'neighbours' extended to firms within a close proximity and not necessarily just next door)'". Consequently, other stakeholders like restaurants, shops, accommodation providers etc. in the cluster (in addition to individual wine producers) benefited from tourists' expenditure and especially repeat tourism, hence aiding the sustainability of businesses in the region. 
Turning to the management of relationships to minimise potential tensions, where possible, the same 16 out of the 20 firms would attempt to capitalise on their own sales, such as if customers required a product or service they offered. Therefore, reciprocal arrangements only went so far in relationships as each business needed to sustain itself through income generation. Nevertheless, if employees knew about their competitors' products and services, and their firm did not offer something that customers asked for, they would recommend one (or more) of their competitors' offerings due to social networks facilitated by a competitor orientation. Additionally, this behaviour influenced the previously mentioned point of enhancing customers' experiences to increase the likelihood of return visits and future wine sales ${ }^{3}$. An example provided by the Cellar Door Manager in Firm 17 illustrates the need for employees to gather information that involved sampling competitors' wines so cross-referrals were possible to enhance respective wine producers' performance. "We often experience times where customers come here and ask for wine that we've never produced, like the other day, some customers came into the cellar door and asked for a bottle of Chardonnay. We don't grow those grapes, so I told them to drive down the road to [firm withheld - competitor] who makes a lovely Chardonnay".

Returning to the link between the RBV and Relational View, the owner-manager of Firm 4 noted the association between knowledge of competitors and resource sharing to add value to customers and enhance performance. He mentioned: "we need to know who [competitors] to team up with for joint promotions as that adds far more value [to customers] than showcasing simply our own wine”. The interviewee added that, "if some of us come together and share the promotional cost, we can create a better experience that gets more customers interested. For some events, it could be a group of us 'showcasing' sav, and other events may do the same for different varietals. So yeah, it's important to know what we all (rivals) can bring to the table and what they can't so to speak." The quote provides an illustration of both resource leveraging behaviour to co-create a value-added customer experience,

\footnotetext{
${ }^{3}$ Theme 2 featured the participant observation (using field notes) of cellar door staff in each of the 20 sampled companies in addition to the interview data.
} 
but also a demonstration of a competitor-orientation with complementary relationships where the strengths and weaknesses of rivals was known to partners.

In the remaining 4 out of the 20 companies that were less keen to indicate that a firm's competitor orientation influences the relationship between value co-creation activities and sales performance, the reasoning was attributed to them having greater resources that enabled them to operate with a more individualistic rather than collaborative business model. Owner-managers nevertheless believed they met sales performance objectives. Despite still recognising the importance of knowing their competitors' activities, they were more likely to accommodate customers' needs themselves to meet objectives. They provided a larger array of wine-related services and wine varietals than the smallersized businesses within the sample. Those in the diversified firms viewed competition to some extent differently to their rivals with a more limited portfolio that served particular product-markets. For example, the owner-manager in Firm 5 expressed knowledge of what competing firms offered, but stated, "we offer all sorts of wine tourism services. We have weddings, we have a fully functional restaurant, we have accommodation all year round, and a great cellar door. When customers come here, we have everything they might want on hand". The quote therefore illustrates that the ownermanagers of firms with a widely augmented business model had less need to collaborate with rivals in their cluster.

Tensions arose in practitioner discourse to varying degrees among all the owner-managers of smallersized firms for three reasons. First, in association with the last point, a perception existed that firms exhibiting greater resources had less need to enter into relationships, since their typically higher number of varietals produced and augmented portfolio (restaurants etc.) suggested they were more self-sufficient. They were nonetheless not fully self-sufficient as they still formed part of certain wine tours; therefore, the tension arose from a perception among rivals as part of a wine tour that employees did not recommend their smaller-sized wine-producing counterparts. As the owner-manager of Firm 4 suggested, "You are right about knowing strengths and weaknesses (of competitors). I think it is 
fair to say that a few of us (smaller-sized) producers have to work hard recommending each other as there are some (rivals) that look after themselves as visitors have more choice and sometimes want to stay there longer. We have to ensure the tour operator gives us all a fair amount of time".

The second potential tension arose from smaller-sized producers in respect of firms within clusters that had formed an alliance with others outside of their region to assist their overseas marketing strategies, and especially those known as the Family of 12 (https://familyoftwelve.co.nz). This alliance provided an example of wine producers that built relationships with others across the north and south islands to offer varietals of New Zealand wine from particular clusters. In doing so, they had knowledge of the strengths and weaknesses of competitors at a national level; however, by building trust and forming an alliance with complementary rivals, they could leverage synergistic strengths and minimise individual weaknesses. A prime example relates to overcoming an issue mentioned earlier involving overseas distributors that may only take one brand of a varietal from a particular region. However, tensions were evident from smaller-sized firms outside of the alliance, as a perception was it acted as a closed shop that would not allow entry and was difficult to compete against members. A common sentiment mentioned by the owner-manager of Firm 11 was "why should I recommend visitors to them (a member of that alliance in their cluster) when they do not help others?"

Finally, the third potential tension resulted from perceived employment practices in particular firms and not least at the cellar door where employees interacted directly with customers. As the ownermanager of Firm 16 pointed out "as you probably know, a lot of temporary workers are taken on at peak times and of course fair enough for harvesting, but my problem is those that work at the cellar door and who provide a poor service. They don't always offer referrals because they may be looking to increase sales and make themselves look good or simply don't know what others (rival firms) have to offer". The quote reflected perceptions towards poor recruitment, training and possible incentives 
regarding students and other temporary workers that did not have knowledge of relationships with competitors and did not facilitate a positive co-created experience that benefited other firms.

Some positive observational illustrations from field notes that supplement the interview data and support proposition 2 were:

[...] sorry, we don't offer many red varietals. If you're [a customer] looking for a decent red wine, drive over to [firm withheld - a competitor] (Firm 2).

[...] rosé wine is hard to come by in [region withheld], we've never made it. My suggestion is that you [a customer] head over to [firm withheld - a competitor]. I believe that they have some at their cellar door (Firm 17).

In contrast, although no outright slanderous comments existed, some negative observational illustrations from field notes highlighting the cause of potential tensions regarding proposition 2 were:

[...] if you're looking for a fuller flavour, I think you would prefer ours over [name of competitor withheld] (Firm 4).

[...] I've heard a few customers complain about them [name of firm withheld] (Firm 18).

\section{Discussion}

\subsection{Contributions Arising from an Evaluation of the Research Propositions}

In terms of the first research proposition, as previously mentioned, existing literature largely establishes the link; hence, the current study offers further support to the notion that value co-creation activities have a positive relationship with sales performance. Specifically, employees being able to co-create a value-added experience via interacting with customers can facilitate the relationship with firms' enhanced performance (Payne et al., 2008; Edvardsson et al., 2011; Tu et al., 2018). As such, the findings related to the first proposition are not surprising. Nevertheless, an under-researched area involves potential intervening factors that may provide unique insights to help explain the relationship and the earlier review of the literature established that a competitor orientation (as per Narver and Slater, 1990) might help in that explanation. However, given the relatively limited existing literature on the specific relationship and the need to understand 'how and why' factors, a qualitative as opposed 
to quantitative investigation appeared appropriate. Therefore, in building on the existing literature, the substantive contribution arises from the second research proposition, namely, that a firm's competitor orientation influences the relationship between value co-creation activities and sales performance.

In the context of the New Zealand wine industry, it appeared that there was a high degree of a competitor orientation, in which employees were highly familiar with and acted upon their rivals' activities, as well as the strengths and weaknesses (Narver and Slater, 1990; Cadogan and Diamantopoulos, 1995; Armstrong and Collopy, 1996). This was especially pertinent at the cluster level building on earlier proximity based research (Letaifa and Rabeau, 2013; Geldes et al., 2015). However, variations were noted across interviewees depending on respective firms' business models (Osterwalder and Pigneur, 2010; Gassmann et al., 2014); that is, having a domestic market wine and tourism focus, or involving wine sales overseas. This current study illustrated examples where a cross-cluster as well as within-cluster competitor orientation was important in enhancing performance and discussion follows in relation to the contributions arising from the investigation.

The first contribution of this study is that unique insights provided illustrations of the benefits for employees having and acting upon knowledge regarding competitors' activities, specifically, in relation to employing value co-creation activities to enhance sales performance. The knowledge gained through firms' respective competitor orientation, helped employees develop capabilities that influenced the resources-performance enhancing perspective associated with the RBV (Barney, 1991, 2014). In particular, the sales performance consequence of value co-creation activities in which value co-creation was a competitive strategy (driven by organisational resources and capabilities) used to improve sales; a common measurement perspective (Verbeke et al., 2008; Katsikeas et al., 2016). Nevertheless, building resources/capabilities was not enough, but rather trust and the quality of network relationships associated with the Relational View (Dyer and Singh, 1998; Dyer et al., 2018) were also evident; that is, adding further support for the theoretical lenses underpinning this current 
investigation. For example, in the event employees were unable to address consumers' needs, or might encourage repeat tourism to a cluster by enhancing customers' experiences (a win/win situation for stakeholders in the cluster), they would recommend a competitor to create a stronger co-created experience, namely, an issue linking with the second contribution as follows.

As such, the second contribution is to outline varying strategies among firms regarding their productmarkets served (Dana and Winstone, 2008; Felzensztein and Deans, 2013; Crick and Crick, 2015; Granata et al., 2018). Existing studies suggest that value co-creation often involves employees extending ordinary market-oriented behaviours, by working with customers to deliver superior value (see Vargo and Lusch, 2004; Ballantyne and Varey, 2008; Edvardsson et al., 2011). In this current investigation, a competitor orientation was a mechanism to help improve organisations' value cocreation activities. As previously noted, a competitor orientation manifests differently related to firms' respective business models and not least aspects involving wine sales and tourism in their domestic market rather than sales of wine overseas. In fact, a competitor orientation was evident across clusters, such as, forming an alliance in serving overseas markets as opposed to much of the existing literature that takes a within-cluster perspective. Therefore, this study provides insights to explain behaviour whereby knowledge of and acting on competitors' behaviour can help the cocreation process in particular ways. The third contribution involves the need to manage tensions (Raza-Ullah et al., 2014; Tidstrom, 2014) and potential negative behaviour resulting from a competitor orientation. Although this study did not find evidence of outright illegal behaviour such as slanderous comments, illustrative examples of subtle negative behaviour and not least, where owner-managers of under-resourced wine producers perceived being 'marginalised' by firms with greater resources and those in alliances. Additionally, where poor recruitment, training and incentives did not facilitate a competitor orientation among certain employees or an enhanced co-created experience. The following section offers conclusions arising from this investigation. 


\section{Conclusions, Implications and Future Research}

\subsection{Conclusions}

The first conclusion is that value co-creation activities are likely to enhance sales performance, although this is already a largely established relationship in earlier studies. The more substantial contributions of this study relate to the other conclusions. The second conclusion is that whilst value co-creation activities are likely to help organisations improve their sales performance, a firm's competitor orientation (employees possessing and acting upon knowledge of their competitors' activities, as well as their strengths and weaknesses) is likely to help businesses develop a superior experience for their customers through value co-creation. This superior experience enhances repeat tourism and hence facilitates sustainability within a cluster, in addition to benefits such as increased revenue for individual firms. Moreover, a broader competitor orientation extends to firms outside of local proximities. As such, firms need to obtain knowledge and build relationships with the most appropriate competitors depending on their product-markets served within business models.

The RBV and its association with the Relational View provide appropriate lenses to offer unique insights into the link between value co-creation activities and sales performance via the role of a firm's competitor orientation. Not least, due to the nature of the resources and capabilities across particular businesses serving various product-markets. It follows that the third conclusion is employees in competing firms need to build trust and develop relationships with complementary rivals. A fourth conclusion is that the proximity within clusters is also important, but only up to a point. Employees in firms that are geographically located further away from competing firms in larger clusters are likely to know less about such competitors and have less developed network ties than those closer and with whom they can more easily co-create activities to enhance customers' experience; for example, via wine tours. However, well-networked employees are able to overcome this by gaining knowledge of competitors further away that might be able to offer performanceenhancing relationships. For example, in terms of offering referrals (with the idea that reciprocation 
takes place) and extending their collaborative strategies that are often with relatively close neighbours. Furthermore, forming alliances with complementary rivals in serving overseas markets. The fifth conclusion is that a need exists to reduce potential tensions that can manifest. A prime example is that owner-managers need to ensure temporary workers do not engage in poor co-created service encounters and especially opportunistic activities depending on administration of incentives within their remuneration. The associated practitioner implications of this investigation follow.

\subsection{Practitioner Implications}

First, owner-managers should consider the merits of their recruitment, training and incentive polices towards employees. While this may appear rather self-evident, operationalising this actually needs greater consideration. Owner-managers need to encourage employees to create a service-driven (cocreated) experience for their customers to maximise the sales performance of their own firm and others in the cluster. By co-creating relationships with customers, staff members are more likely to be able to learn new ways to satisfy their wants and needs, and in turn, become competent at being responsive to customers' requirements. A possible way for this to take place involves new employees working with more experienced staff to establish what works and does not work at cellar doors. For the recruitment of placement students attending college courses, it is possible that their respective course contains a business component where customer service features, like a Tourism degree (or even if their specialism is Viticulture). However, a potentially greater problem lies with the recruitment of temporary workers with no business training where mentoring and shadowing the behaviour of an experienced colleague provides a practical training option. Appropriate incentives are important to avoid opportunistic behaviour, such as, the way implementation of commissions takes place and an experienced supervisor should monitor such behaviour.

Second, on a related point, employees should attempt to understand their rivals' strengths and weaknesses and use such knowledge in their respective firm's performance-enhancing value co- 
creation activities. That is, if employees understand how their competitors' activities compare against their own firm's operations, they might be able to develop superior value co-creation activities. In doing so, it is important that not just owner-managers visit competing firms, but also employees. In reality, formal agreements are likely to be at the owner-manager level, but this does not prevent employees visiting counterparts in order to gain operational knowledge to facilitate joint referrals. For example, learning about competitors' wine varietals in addition to menus if counterparts have a restaurant, etc. Furthermore, by developing personal relationships across functional level employees at cellar doors, this can build trust within relationships. For clarity, such complementary relationships are likely to develop where direct rivalry is not present among firms. It follows that employees in smaller-sized firms in particular could create a stronger experience for customers by recommending other companies that will satisfy their requirements as long as it is not at the expense of their own business. In principle, rivals would employ reciprocal arrangements in return for a win/win arrangement (an issue that needs monitoring to minimise tensions, Raza-Ullah et al., 2014; Tidstrom, 2014). The limitations and avenues for future research follow in the next section.

\subsection{Limitations and Avenues for Future Research}

The New Zealand wine industry was a suitable setting for this study with business models addressing various product-markets. For example, due to the wide array of wines sold domestically and overseas together with tourism and related value co-creation activities within various clusters. However, the qualitative data in this study may not be transferable to certain other contexts based on the sample size together with potential sector and country differences. In fact, future research can increase the number of interviewees in networked relationships within the same cluster, to enhance understanding of dynamics associated with particular rural contexts. For example, across members of supply chains such as growers, producers etc. Additionally, the role of institutional factors, such as, governing and support organisations. It would be useful to investigate other sectors containing firms in rural clusters, 
such as, accommodation providers that may include farms that have diversified their business models away from the core activity of farming. There may be cultural differences that manifest across regions in particular countries that are worthy of further research.

However, within the sector under consideration in this current study, as Charters and Ali-Knight (2002) note, the wine tourist is not homogeneous. Future research is useful to investigate co-created experiences among different types of visitors (like novice versus experienced wine drinkers, etc.) across countries. Moreover, how a competitor orientation can enhance particular types of customers' experiences based on the value of the service offering provided at cellar doors. One example includes future research on negative behaviour that impact on the performance of particular firms at the expense of others. A related study might investigate retaliatory behaviour in response to opportunistic activities. Indeed, subject to access issues, this may involve an ethnographic study to investigate employee/customer interactions. Additionally, subject to facilitating access to data that may be difficult, longitudinal case studies also provide avenues to explore how/why issues in greater depth. An example involves addressing practical recommendations arising from this study in terms of what works and does not work in respect of training; also, why. Investigations similar to this will increase the practical impact of studies in addition to contributing to knowledge. In terms of a further academic contribution, future investigations should aim to operationalise, and test, the issues developed within this study using numerical data. Specifically, testable research hypotheses to arrive at generalizable results can follow in future research. In closing, despite this current investigation's contribution to the existing cross-disciplinary literature, avenues exist to develop the research in future studies to further understanding regarding ways that firms engage in strategies to aid the sustainability of rural clusters, including firms that need to collaborate with rivals across clusters to maintain a competitive advantage.

\section{Declarations of Interest}

None. 


\section{References}

Afonso, C., Silva, G.M., Gonçalves, H.M., and Duarte, M. (2018) The role of motivations and involvement in wine tourists' intention to return: SEM and fsQCA findings. Journal of Business Research, 89(Aug), 313-321.

Alsos, G.A. and Carter, S. (2006) Multiple business ownership in the Norwegian farm sector: Resource transfer and performance consequences. Journal of Rural Studies, 22(3), 313-322.

Alves, H., Fernandes, C., and Raposo, M. (2016) Value co-creation: Concept and contexts of application and study. Journal of Business Research, 69(5), 1626-1653.

Argent, N. (2018) Heading down to the local? Australian rural development and the evolving spatiality of the craft beer sector. Journal of Rural Studies, 61(July), 84-99.

Armstrong, J.S. and Collopy, F. (1996) Competitor orientation: Effects of objectives and information on managerial decisions and profitability. Journal of Marketing Research, 33(2), 188-199.

Aylward, D.K. (2003) A documentary of innovation support among New World wine industries. Journal of Wine Research, 14(1), 31-43.

Baird, T., Hall, C.M., and Castka, P. (2018) New Zealand winegrowers attitudes and behaviours towards wine tourism and sustainable winegrowing. Sustainability, 10(3), 797.

Ballantyne, D. and Varey, R.J. (2008) The service-dominant logic and the future of marketing. Journal of the Academy of Marketing Science, 36(1), 11-14.

Barney, J.B. (1991) Firm resources and sustained competitive advantage. Journal of Management, 17(1), 99-120.

Barney, J.B. (2014) How marketing scholars might help address issues in resource-based theory. Journal of the Academy of Marketing Science, 42(1), 24-26.

Barney, J.B. (2018) Why resource-based theory's model of profit appropriation must incorporate a stakeholder perspective. Strategic Management Journal, 39(13), 3305-3325.

Bendapudi, N. and Leone, R.P. (2003) Psychological implications of customer participation in coproduction. Journal of Marketing, 67(1), 14-28.

Beverland, M.B. (2005) Crafting brand authenticity: The case of luxury wines. Journal of Management Studies, 42(5), 1003-1029.

Bonn, M.A., Cho, M., and Um, H. (2018) The evolution of wine research: a 26 year historical examination of topics, trends and future direction. International Journal of Contemporary Hospitality Management, 30(1), 286-312.

Brandth, B. and Haugen, M.S. (2011) Farm diversification into tourism - Implications for social identity. Journal of Rural Studies, 27(1), 35-44. 
Brown, G. and Getz, D. (2005) Linking wine preferences to the choice of wine tourism destinations. Journal of Travel Research, 43(3), 266-276.

Bruwer, J. (2003) South African wine routes: Some perspectives on the wine tourism industry's structural dimensions and wine tourism product. Tourism Management, 24(4), 423-435.

Bruwer, J., Prayag, G., and Disegna, P. (2018) Why wine tourists visit cellar doors: Segmenting motivation and destination image. International Journal of Tourism Research, 20(3), 355-366.

Cabiddu, F., Lui, T-W., and Piccoli, G. (2013) Managing value co-creation in the tourism industry. Annals of Tourism Research, 42(1), 86-107.

Cadogan, J.W. and Diamantopoulos, A. (1995) Narver and Slater, Kohli and Jaworski and the market orientation construct: Integration and internationalization. Journal of Strategic Marketing, 3(1), 41-60.

Charters, S. and Ali-Knight, J. (2002) Who is the wine tourist? Tourism Management, 23(3), 311319.

Charters, S. and Michaux, V. (2014) Strategies for wine territories and clusters: Why focus on territorial governance and branding? Journal of Wine Research, 25(1), 1-4.

Charters, S., Fountain, J., and Fish, N. (2009) "You felt like lingering...": Experiencing "real" service at the winery tasting room, Journal of Travel Research, 48(1), 122-134.

Chathoth, P.K., Ungson, G.R., Harrington, R.J. and Chan, E.S.W. (2016) Co-creation and higher order customer engagement in hospitality and tourism services: a critical review. International Journal of Contemporary Hospitality Management, 28(2), 222-245.

Combs, J.G. and Ketchen Jr, D.J. (1999) Explaining inter-firm cooperation and performance: Toward a reconciliation of predictions from the resource-based view and organizational economics. Strategic Management Journal, 20(9), 867-888.

Cradock-Henry, N.A. and Fountain, J. (2019) Characterising resilience in the wine industry: Insights and evidence from Marlborough, New Zealand. Environmental Science \& Policy, 94(April), 182-190.

Crick, D. and Crick, J.M. (2015) Learning and decision-making in marketing planning: A study of New Zealand vineyards. Marketing Intelligence \& Planning, 33(5), 707-732.

Crick, D., Chaudhry, S., and Crick, J.M. (2016) Trading in a competitive environment: South-Asian restaurants in the UK. Strategic Change, 25(4), 371-382.

Crick, J.M. (2018) The facets, antecedents and consequences of coopetition: An entrepreneurial marketing perspective. Qualitative Market Research: An International Journal, 21(2), 253-272.

Dana, L-P., Granata, J., Lasch, F., and Carnaby, A. (2013) The evolution of co-opetition in the Waipara wine cluster of New Zealand. Wine Economics and Policy, 2(1), 42-49. 
Dana, L-P. and Winstone, K.E. (2008) Wine cluster formation in New Zealand: Operation, evolution and impact. International Journal of Food Science and Technology, 43(12), 2177-2190.

Dawson, D., Fountain, J., and Cohen, D.A. (2011) Seasonality and the lifestyle "conundrum": An analysis of lifestyle entrepreneurship in wine tourism regions. Asia Pacific Journal of Tourism Research, 16(5), 551-572.

Day, G.S., Deighton, J., Narayandas, D., Gummesson, E., Hunt, S.D., Prahalad, C.K., Rust, R.T., and Shugan, S.M. (2004) Invited commentaries on "evolving to a new dominant logic for marketing. Journal of Marketing, 68(1), 18-27.

Dias, C.S.L., Rodrigues, R.G., and Ferreira, J.J. (2019) What's new in the research on agricultural entrepreneurship? Journal of Rural Studies, 65(Jan), 99-115.

Dyer, J.H. and Singh, H. (1998) The relational view: Cooperative strategy and sources of interorganizational competitive advantage. Academy of Management Review, 23(4), 660-679.

Dyer, J.H., Singh, H., and Hesterly, W.S. (2018) The relational view revisited: A dynamic perspective on value creation and value capture. Strategic Management Journal, 39(12), 3140-3162.

Edvardsson, B., Tronvoll, B., and Gruber, T. (2011) Expanding understanding of service exchange and value co-creation: A social construction approach. Journal of the Academy of Marketing, Science, 39(2), 327-339.

Escalona-Orcao, A.I., Escolano-Utrilla, S., Saez-Perez, L.A., and Sanchez-Valverde Garcia, B. (2016) The location of creative clusters in non-metropolitan areas: A methodological proposition. Journal of Rural Studies, 45(June), 112-122.

Family of 12 (2019) https://familyoftwelve.co.nz (accessed various dates).

Felzensztein, C. and Deans, K.R. (2013) Marketing practices in wine clusters: Insights from Chile. Journal of Business \& Industrial Marketing, 28(4), 357-367.

Felzensztein, C., Brodt, S. E., and Gimmon, E. (2014a) Do strategic marketing and social capital really matter in regional clusters? Lessons from an emerging economy of Latin America. Journal of Business Research, 67(4), 498-507.

Felzensztein, C., Stringer, C., Benson-Rea, M., and Freeman, S. (2014b) International marketing strategies in industrial clusters: Insights from the Southern Hemisphere. Journal of Business Research, 67(5), 837-846.

Felzensztein, C., Gimmon, E., and Deans, K. (2018) Coopetition in regional clusters: Keep calm and expect unexpected changes. Industrial Marketing Management, 69(Feb), 116-124.

Felzensztein, C., Deans, K.D., and Dana, L-P. (2019) Small firms in regional clusters: Local networks and internationalization in the Southern Hemisphere. Journal of Small Business Management, 57(2), 496-516.

Fountain, J. (2018) The wine tourism experience in New Zealand: An investigation of Chinese visitors' interest and engagement. Tourism Review International, 22(1), 67-79. 
Fountain, J., Fish, N., and Charters, S. (2008) Making a connection: Tasting rooms and brand loyalty. International Journal of Wine Business Research, 20(1), 8-21.

Gassmann, O., Frankenberger, K., and Csik, M. (2014) The Business Model Navigator. Harlow: FT Publishing.

Geldes, C., Felzensztein, C., Turkina, E., and Durand, A. (2015) How does proximity affect interfirm marketing cooperation? A study of an agribusiness cluster. Journal of Business Research, 68(2), 263-272.

Gioia, D.A., Corley, K.G., and Hamilton, A.L. (2013) Seeking qualitative rigor in inductive research: Notes on the Gioia methodology. Organizational Research Methods, 16(1), 15-31.

Granata, J., Lasch, F., Le Roy, F., and Dana, L-P. (2018) How do micro-firms manage coopetition? A study of the wine sector in France. International Small Business Journal, 36(3), 331-355.

Gray, B.J., Matear, S.M., and Matheson, P.K. (2000) Improving the performance of hospitality firms. International Journal of Contemporary Hospitality Management, 12(3), 149-155.

Grönroos, C. and Voima, P. (2013) Critical service logic: Making sense of value creation and cocreation. Journal of the Academy of Marketing Science, 41(2), 133-150.

Hall, C.M. and Mitchell, R. (2000) Wine tourism in the Mediterranean: A tool for restructuring and development. Thunderbird International Business Review, 42(4), 445-465.

Hansson, H., Ferguson, R., Olofsson, C., and Rantamaki-Lahtinen, L. (2013) Farmers' motives for diversifying their farm business - The influence of family. Journal of Rural Studies, 32(Oct), 240-250.

Hayward, D. and Lewis, N. (2008) Regional dynamics in the globalising wine industry: The case of Marlborough, New Zealand. The Geographical Journal, 174(2), 124-137.

Hollebeek, L.D. and Brodie, R.J. (2009) Wine service marketing, value co creation and involvement: Research issues. International Journal of Wine Business Research, 21(4), 339-353.

Howland, P.J. (ed.) (2014) Social, Cultural and Economic Impacts of Wine in New Zealand. Oxon: Routledge.

Jansen, S. and Pieters, M. (2017) The 7 Principles of Complete Co-creation. Amsterdam: BIS Publishers.

Jaskiewicz, P., Combs, J.G., and Rau, S.B. (2015) Entrepreneurial legacy: Toward a theory of how some family firms nurture transgenerational entrepreneurship. Journal of Business Venturing, 30(1), 29-49.

Jones, R. and Rowley, J. (2011) Entrepreneurial marketing in small businesses: A conceptual exploration. International Small Business Journal, 29(1), 25-36. 
Katsikeas, C.S., Morgan, N.A., Leonidou, L.C., and Hult, G.T.M. (2016) Assessing performance outcomes in marketing. Journal of Marketing, 80(2), 1-20.

Lee, A.H.J., Wall, G., and Kovacs, J.F. (2015) Creative food clusters and rural development through place branding: Culinary tourism initiatives in Stratford and Muskoka, Ontario, Canada. Journal of Rural Studies, 39(June), 133-144.

Letaifa, S.B. and Rabeau, Y. (2013) Too close to collaborate? How geographic proximity could impede entrepreneurship and innovation. Journal of Business Research, 66(10), 2071-2078.

Le Roy, F.L. and Sanou, F.H. (2014) Does coopetition strategy improve market performance? An empirical study in mobile phone industry. Journal of Economics and Management, 17(1), 6394.

Li, X., and Petrick, J.F. (2008) Tourism marketing in an era of paradigm shift. Journal of Travel Research, 46(3), 235-244.

Madhavaram, S. and Hunt, S.D. (2008) The service-dominant logic and a hierarchy of operant resources: Developing masterful operant resources and implications for marketing strategy. Journal of the Academy of Marketing Science, 36(1), 67-82.

McNally, S. (2001) Farm diversification in England and Wales - what can we learn from the farm business survey? Journal of Rural Studies, 17(2), 247-257.

Mitchell, R., Charters, S., and Albrecht, J.N. (2012) Cultural systems and the wine tourism product. Annals of Tourism Research, 39(1), 311-335.

Mitchell, R. and Hall, C.M. (2001) Lifestyle behaviours of New Zealand winery visitors: Wine club activities, wine cellars and place of purchase. International Journal of Wine Marketing, 13(3), 82-93.

Mitchell, R. and Hall, C.M. (2003) Seasonality in New Zealand winery visitation: An issue of demand and supply. Journal of Travel \& Tourism Marketing, 14(3-4), 155-173.

Mitchell, R. and Schreiber, C. (2006) Wine tourism networks and clusters: Operation and barriers in New Zealand. In Micro-Clusters and Networks: The Growth of Tourism (Ed) Ewen, M., Oxford: Elsevier, 99-126.

Morrow, S.L. (2005) Quality and trustworthiness in qualitative research in counseling psychology. Journal of Counseling Psychology, 52(2), 250-260.

Murray, W.E. and Overton, J. (2011) Defining regions: the making of places in the New Zealand wine industry. Australian Geographer, 42(4), 419-433.

Narver, J.C. and Slater, S.F. (1990) The effect of a market orientation on business profitability. Journal of Marketing, 54(4), 20-35.

New Zealand Winegrowers. (2018) A land like no other. Available on the New Zealand Winegrowers website at: https://www.nzwine.com/media/6390/a-land-like-no-other.pdf (accessed on various dates including during the resubmission stage in 2019). 


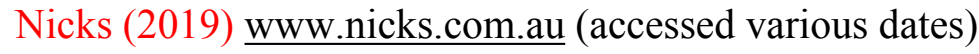

O'Cass, A. and Ngo, L.V. (2011) Examining the firm's value creation process: A managerial perspective of the firm's value offering strategy and performance. British Journal of Management, 22(4), 646-671.

Onederra-Aramendi, A., Begiristain-Zubillaga, M., and Malagon-Zaldua, E. (2018) Who is feeding embeddedness in farmers' markets? A cluster study of farmers' markets in Gipuzkoa. Journal of Rural Studies, 61(July), 22-33.

O'Neill, M., Palmer, A., and Charters, S. (2002) Wine production as a service experience - The effects of service quality on wine sales. Journal of Services Marketing, 16(4), 342-362.

Osterwalder, A. and Pigneur, Y. (2010) Business Model Generation. New Jersey: John Wiley \& Sons Ltd.

Overton, J. and Heitger, J. (2008) Maps, markets and Merlot: The making of an antipodean wine appellation. Journal of Rural Studies, 24(4), 440-449.

Overton, J. and Murray, W.E. (2011) Playing the scales: Regional transformations and the differentiation of rural space in the Chilean wine industry. Journal of Rural Studies, 27(1), 6372 .

Payne, A.F., Storbacka, K., and Frow, P. (2008) Managing the co-creation of value. Journal of the Academy of Marketing Science, 36(1), 83-96.

Perkins, H.C., Mackay, M., and Espiner, S. (2015) Putting pinot alongside merino in Cromwell District, Central Otago, New Zealand: Rural amenity and the making of the global countryside. Journal of Rural Studies, 39(June), 85-98.

Porter, M.E. (2000) Location, competition, and economic development: Local clusters in a global economy. Economic Development Quarterly, 14(1), 15-34.

Prahalad, C.K. and Ramaswamy, V. (2004) The Future of Competition: Co-Creating Unique Value With Customers. Boston: Harvard Business School Press.

Prebensen, N.K. and Xie, J. (2017) Efficacy of co-creation and mastering on perceived value and satisfaction in tourists' consumption. Tourism Management, 60(1), 166-176.

Prebensen, N.K., Vittersø, J., and Dahl, T.I. (2013) Value co-creation significance of tourist resources. Annals of Tourism Research, 42(1), 240-261.

Priem, R.L. and Butler, J.E. (2001) Is the resource-based view a useful perspective for strategic management research? Academy of Management Review, 26(1), 57-66.

Randall, C. and Mitchell, R. (2008) Wine tourism marketing alliances application of importancePerformance analysis. Tourism Recreation Research, 33(3), 289-302.

Rainer, G. (2016) Constructing globalized spaces of tourism and leisure: Political ecologies of the Salta Wine Route (NW-Argentina). Journal of Rural Studies, 43(Feb), 104-117. 
Ramírez, R. (1999) Value co-production: Intellectual origins and implications for practice and research. Strategic Management Journal, 20(1), 49-65.

Ranjan, K.R. and Read, S. (2016) Value co-creation: Concept and measurement. Journal of the Academy of Marketing Science, 44(3), 290-315.

Raza-Ullah, T., Bengtsson, M., and Kock, S. (2014) The coopetition paradox and tension in coopetition at multiple-levels. Industrial Marketing Management, 43(2), 189-198.

Riley, R.W. and Love, L.L. (2000) The state of qualitative tourism research. Annals of Tourism Research, 27(1), 164-187.

Ritala, P. (2012) Coopetition strategy - When is it successful? Empirical evidence on innovation and market performance. British Journal of Management, 23(3), 307-324.

Seilov, G.A. (2015) Does the adoption of customer and competitor orientations make small hospitality businesses more entrepreneurial?: Evidence from Kazakhstan. International Journal of Contemporary Hospitality Management, 27(1), 71-86.

Sinkovics, R.R. and Alfoldi, E.A. (2012) Progressive focusing and trustworthiness in qualitative research: The enabling role of computer-assisted qualitative data analysis software (CAQDAS). Management International Review, 52(6), 817-845.

Slater, S.F. (1997) Developing a customer value-based theory of the firm. Journal of the Academy of Marketing Science, 25(2), 162-167.

Slater, S.F. and Narver, J.C. (2000) The positive effect of a market orientation on business profitability: A balanced replication. Journal of Business Research, 48(1), 69-73.

Sørensen, F. and Jensen, J.F. (2015) Value creation and knowledge development in tourism experience encounters. Tourism Management, 46(1), 336-346.

Stake, R.E. (1995) The Art of Case Study Research. Thousand Oaks: Sage Publications.

Telfer, D.J. (2001) Strategic alliances along the Niagara Wine Route. Tourism Management, 22(1), 21-30.

Tidström, A. (2014) Managing tensions in coopetition. Industrial Marketing Management, 43(2), 261-271.

Tosey, P., Lawley, J., and Meese, R. (2014) Eliciting metaphor through clean language: An innovation in qualitative research. British Journal of Management, 25(3), 629-646.

Tu, Y., Neuhofer, B., and Viglia, G. (2018) When co-creation pays: stimulating engagement to increase revenues. International Journal of Contemporary Hospitality Management, 30(4), 2093-2111.

Vargo, S.L. and Lusch, R.F. (2004) Evolving to a new dominant logic for marketing. Journal of Marketing, 68(1), 1-17. 
Vargo, S.L. and Lusch, R.F. (2008) Service-dominant logic: Continuing the evolution. Journal of the Academy of Marketing Science, 36(1), 1-10.

Verbeke, W.J., Belschak, F.D., Bakker, A.B., and Dietz, B. (2008) When intelligence is (dys)functional for achieving sales performance. Journal of Marketing, 72(4), 44-57.

Voronov, M., De Clercq, D., and Hinings, C.R. (2013) Conformity and distinctiveness in a global institutional framework: The legitimation of Ontario fine wine. Journal of Management Studies, 50(4), 607-645.

Wang, G. and Miao, C.F. (2015) Effects of sales force market orientation on creativity, innovation implementation, and sales performance. Journal of Business Research, 68(11), 2374-2382.

Winchester, H.P.M. and Rofe, M.W. (2010) Qualitative research and its place in human geography, in I. Hay (ed.) Qualitative Research Methods in Human Geography (3 ${ }^{\text {rd }}$ Ed). Don Mills, Ontario: Oxford University Press. 3-25.

Woodfield, P. and Husted, K. (2017) Intergenerational knowledge sharing in family firms: Casebased evidence from the New Zealand wine industry. Journal of Family Business Strategy, 8(1), 57-69.

$\mathrm{Wu}, \mathrm{J}-\mathrm{J}$. (2004) Influence of market orientation and strategy on travel industry performance: An empirical study of e-commerce in Taiwan. Tourism Management, 25(3), 357-365. 


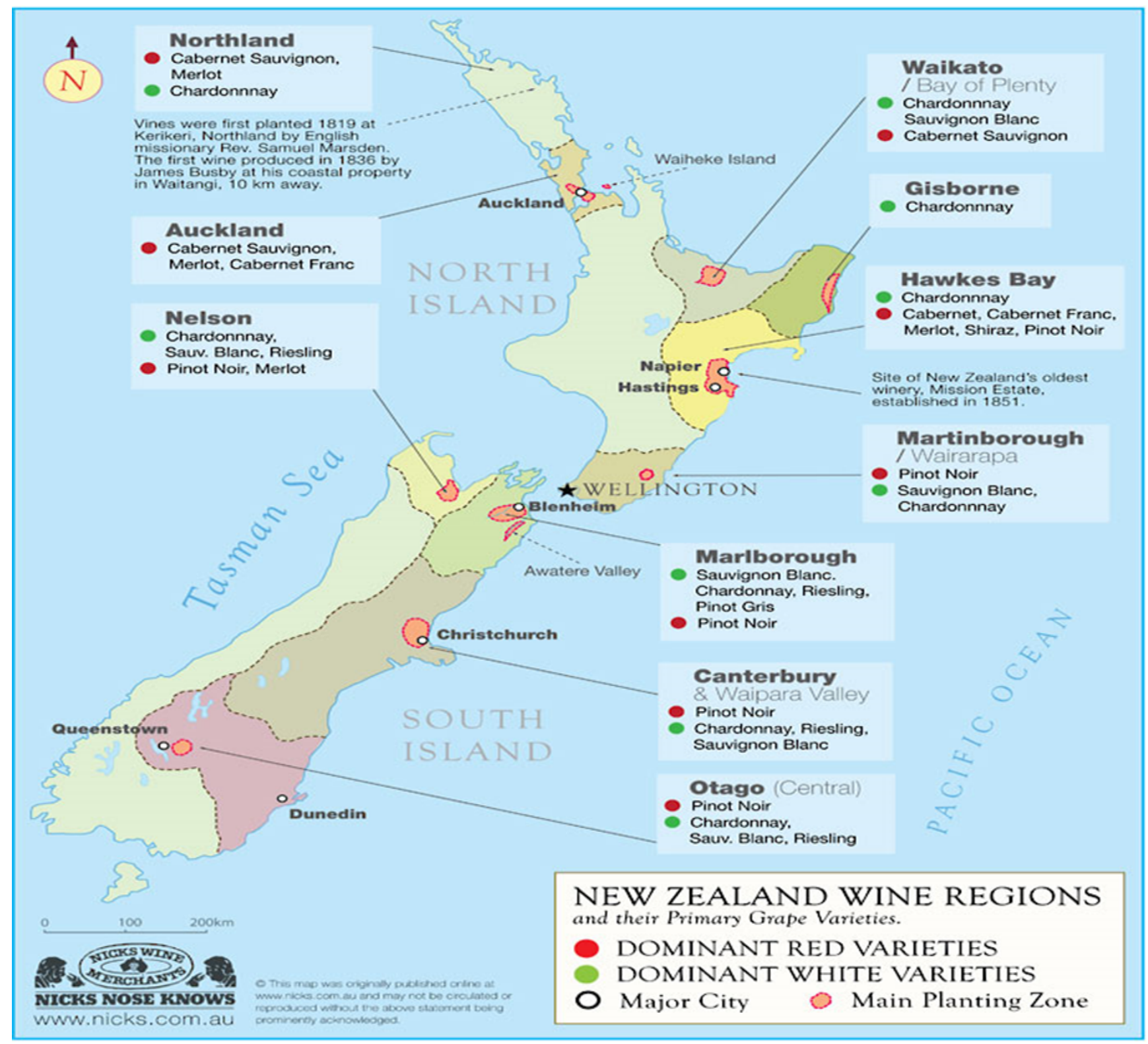

Sourced from: www.nicks.com.au 